
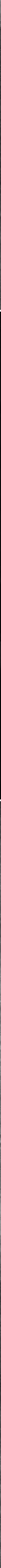

Jim Shaw da série "pinturas encontradas em lojas de quinquilharias", 2007

Fotos: f. marquespenteado realizadas na exposição Frankfurter Kunstverein, Alemanha (dez. 2008-mar. 2009)

\title{
De tempos em tempos
}

Há algum tempo eu perseguia, e com isso me cobrava, uma percepção mais esclarecida em relação à ecologia dentro do universo dos têxteis e da moda. Só ultimamente, entretanto, encontrei um material de pesquisa sério que pôde me dar uma visão ampla e bem alicerçada do "tamanho da encrenca" e com o qual consegui inclusive refletir sobre o porquê de minha própria morosidade em relação ao assunto. 0 texto menciona a distinção que os gregos faziam dos sintomas do tempo em que se vive, sendo Káiros o tempo das "oportunidades que se dão em momentos propícios" e Kronos o tempo "eterno e incessante". Com essa distinção pude perceber em mim a dificuldade que, imagino, muitos temos em tomar nas mãos problemas que nos cercam e agir diante deles que nos parecem distantes, em um tempo ao qual não pensamos estar alinhados: somos sim incessantemente dragados para o tempo do agora e chamados a estar alerta para não perder oportunidades. E com isso os temas sociais e ambientais que exigem (de mim) incisão de conduta, ativismo político e posições 


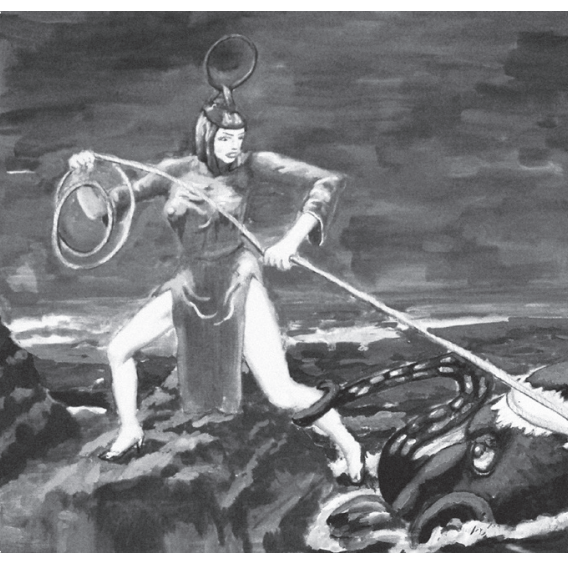

críticas ficam maquiados pelo tempo do hoje com suas pressões, tempos que nos cobram posições como sujeitos modernos, produtivos e afiados em tecnologias lubrificadas por estilos de consumo. Esse material que li serviu para conhecer agentes, desde sujeitos de dentro da indústria até chegar ao designer e ao consumidor, que já vêm processando boas práticas e uma conscienciosa projeção de futuro a longo prazo no que diz respeito à questão ambiental: nos passos desses cidadãos vive um tempo expandido.

0 texto em questão é Sustainable fashion \& textiles: design journeys, de Kate Fletcher (2008). A noção de sustentabilidade, palavra já inscrita no próprio título do livro, encabeça durante todo o texto um projeto a longo prazo, uma disposição edificante que não se acomoda em um cabide matreiro de marketing de responsabilidades individuais e corporativas; a visão de sustentabilidade é tratada com a preocupação de que ela venha a se inscrever no design dos futuros produtos $\mathrm{e}$, por isso, necessariamente olhando para o ciclo completo de existência desses novos produtos, desde a produção até o descarte. A coluna [ picote] nesta edição nada mais é que minha seleção de fatos, estratégias e depoimentos que o livro contém. Decidi começar por traduzir as posições e as criticas que Fletcher traz ligadas à moda, antes de falar sobre as frágeis instâncias dos têxteis. Isso porque, curiosamente, sou constantemente convidado a dar um parecer em relação às dinâmicas da moda at large, as quais eu acompanho a uma distância bem controlada e, nessas oportunidades em que me vejo falando ou escrevendo sobre moda, tenho a percepção de que o que eu disse é ou pode ser visto ou lido como "leviano, ácido, alheio ou picante". Entretanto, leiam vocês as incisivas posições abaixo, com as quais de fato comungo e que, infelizmente, raramente vejo postas em perspectiva hoje nos estudos de moda a que tenho acesso. Peço ao leitor que me redirecione a textos e a fóruns de debate brasileiros com conteúdos adjacentes aos que seguem.

Na obra, um dos argumentos centrais é o do efeito por trás do descarte irrefletido de qualquer bem material, gesto que anula o (re)conhecimento da energia que esse objeto incorpora: no caso aqui, o efeito da peça de roupa quando é descartada. Os ciclos da moda conhecidamente contribuem em niveis marcantes para o consumo material individual. Novas visões para a estrutura do mercado da moda deveriam trabalhar não tanto com mensagens anticonsumistas, como mais propriamente para a ampliação de uma mentalidade que proclame a importância da moda na cultura, mas que reconheça a urgência de uma agenda que inclua práticas que fomentem a sustentabilidade. Uma atividade de moda que não presta atenção aos aspectos morais (pagamentos 
irresponsáveis de salário, não-contratação do empregado, exaustivas e desumanas horas de trabalho, uso de mão de obra infantil etc.) e ambientais (ciclos de produção com taxas de emissão de poluentes, excessos químicos despejados em mananciais, entre outros) minimiza os valores da vida em sociedade e da ecologia ambiental. A meta é dirigir-se para uma sociedade conhecedora dos ciclos econômicos - leia-se o de produzir e o de descartar - e dos materiais que processa, a qual pensa e age para declinar drasticamente o que virá a descartar, pois 90\% dos recursos retirados do solo atualmente no mundo tornam-se lixo em menos de três meses. Assim, qualquer produto industrial que venha a ser desenhado deve buscar sua, hoje inalienável, compatibilidade ecológica e conter pelo menos um dos dois ciclos de produção tidos como "corretos": o ciclo biológico, no qual o circuito do produto é fechado quando ele é devolvido inofensivamente à natureza e em condições biológicas reabsorvíveis; ou o ciclo industrial, em que, na produção do novo produto, o circuito é fechado quando se faz uso de uma reciclagem completa e contínua de materiais e de produtos não biodegradáveis.

No livro, a indústria da moda é duramente criticada pelo fomento ao descarte, pois o consumo de roupas está ligado tanto ao comprar quanto ao dispor ou rejeitar uma peça em detrimento de uma nova. A moda mostra a sua pior face enquanto alimenta inseguranças, provoca pressão no grupo de referência dos sujeitos, causa o estresse, agrava condições médicas e promove pensamentos imediatistas: a indústria projeta consumidores passivos de produtos homogêneos, cujo desenho mítico se origina no altar das passarelas, o que permite que o sistema da moda mistifique, controle e profissionalize a prática de desenhar e de fazer roupas. Fletcher (2008) sugere que a moda desloque seus projetos estratégicos enquanto mero acúmulo de riqueza material e passe a investir sim na motivação individual dos sujeitos para o uso de suas próprias ideias e habilidades ao satisfazer as suas necessidades. A nova ética da moda se inscreve no fazer de pequenos produtores, atores com produções flexíveis e tiragens menores, mais expressivas e diversificadas, nas quais o consumidor retoma a possibilidade de se conscientizar sobre a origem e o correto investimento material e ambiental da peça que estará vestindo. Essa possibilidade provocaria a revitalização de um senso de si próprio e, caso se possa falar assim, provocaria uma re-humanização por meio da roupa que o sujeito usa. Nesses cenários, ao sujeito investidor são dadas maiores oportunidades de escolha em relação ao que veste, enquanto as peças, elas mesmas, revelam e informam mais sobre os indivíduos que as confeccionam, procurando acordar o sujeito investidor do torpor que o levou a, provavelmente, nunca entrar em contato com as más condições salariais e os raros investimentos ambientais incorporados nos itens de vestuário que possuiu e, assim, mudar esse comportamento diante de qualquer peça que esteja decidido a comprar. Por trás dessa visão estética e de comportamento está o esforço em conseguir amputar os ditames subliminares incorporados às veiculações de produtos de marcas de elite que reforçam a ideia de que é possivel e, mesmo desejável, sermos ética e politicamente neutros.

Ao ver que ainda havia muito por dizer e poucas linhas para isso, decidi tratar deste tema da sustentabilidade em um formato-seriado, e assim continuar pondo lenha na fogueira na próxima edição. Deixo para este rabicho de coluna um comentário que adocica a posição de Fletcher (2008), a qual, mesmo que brevemente, cutuca a agenda estética das artes contemporâneas e seu descompromisso político. Sou o primeiro a concordar que as artes não exercitam o que acredito ser a sua vocação prioritária, que é a de se fazer perceber e responder na comunidade onde ela nasce e à qual se destina como sensor da vida. Muitas das direções dentro das artes praticam demais um ideário racionalista e embelezador no que diz respeito à estética dos objetos e, no caso do Brasil, em especial, vejo a produção artística contemporânea bastante revisionista e com acertos e aprumos para o mercado antes mesmo de os trabalhos fazerem ver as poéticas mais esquizofrênicas e, por isso mesmo, mais interessantes dos artistas. Assim, descrevo brevemente os exemplos de dois artistas que furam espaços de sentido e propõem perguntas e imagens que, creio, ajudam nosso contexto. 
